\title{
Blended Learning Approach for Students with Special Educational Needs: A Systematic Review
}

\author{
Esmaeil Zaraii Zavaraki \\ Associate Professor \\ Faculty of Psychology and Educational Sciences \\ Allameh Tabataba'i University \\ Tehran, Iran \\ Daniel Schneider \\ Associate Professor \\ Faculty of Psychology and Educational Sciences \\ University of Geneva \\ Geneva, Switzerland
}

\begin{abstract}
The paper presents evidence around derived from a systematic review of the literature on the blended learning approach for students with special educational needs. A comprehensive search through multiple known databases identified a dataset of 142 papers from which 22 papers met the criteria for in-depth analysis. The analysis revealed that approach, environment, learner, tools, support and evaluation are categories of extracted in blended learning approach for students with special educational needs. The elements of each category are introduced and explained in the article. However besides presenting the evidence found in literature, our analysis highlights that researching the effect of blended learning approach on SEN students remains an under-explored area of study. Few high-quality studies were found to evaluate the role of blended learning in special education, and those that were found provide only rudimentary evidence that integrating advanced technology with traditional approaches have potential to enrich learning environment among SEN students. Further well-designed research into the use of blended learning approach in special education is therefore needed.
\end{abstract}

Keywords: blended learning approach, hybrid learning, digital learning, technology-enhanced learning, special education

\section{Introduction}

Over the past decade, digital and online learning options have become more popular and more widely used in public schools, although many schools have been slow or reluctant to adopt new technologies for number of complex reasons, ranging from inadequate funding, technologies, and computing networks to general organizational recalcitrance and resistance to change. In many cases, blended learning is one component of a larger reform initiative in a school or district (Abbott, 2014).

Blended learning refers to the systematic integration of online and face-to-face engagement to support and enhance meaningful interaction between students, teachers and resources (Garrison and Kanuka, 2004). Blended learning offers many potential advantages and disadvantages that will largely depend on the quality of the learning design and model. Blended learning gives students with special educational needs the benefits of both online learning and in-person instruction. For example, students can work independently and at their own pace online, but still have access to the personal attention of a teacher and all the assistance, knowledge, and resources such an educator provides. At the same time, teachers can structure courses and deliver instruction more flexibly or creatively than in a traditional classroom setting. According to Christensen, Horn, and Staker (2013, p.9), blended learning is defined as: "a formal education program in which a student learns at least in part through online learning with some element of student control over time, place, path, and/or pace and at least in part at a supervised brick-and-mortar location away from home. The modalities along each student's learning path within a course or subject are connected to provide an integrated learning experience." The study defined blended learning as "Blended learning, also referred to as hybrid learning, combines the best features of traditional schooling with the advantages of online learning to deliver personalized, differentiated instruction across a group of learners. Students in formal blended learning educational programs learn online part of the 
time, yet have the benefit of face-to-face instruction and supervision to maximize their learning and to best fit their own needs. (Powellet al. 2015, p.5).

Blended learning may also allow teachers to spend less time giving whole-class lessons, and more time meeting and interacting with students with special educational needs individually or in small groups to help them with specific concepts, skills, questions, or learning problems. In blended-learning situations, students with special educational needs are required to use digital and online technologies and they naturally acquire more technological literacy and greater confidence using new technologies, which is very essential in 21 century life and in future.

Inclusive education means that all students attend and are welcomed by their neighborhoods schools in age-appropriate, regular classes and are supported to learn, contribute and participate in all aspects of the life of the school. Inclusion in education is an approach to educating students with special educational needs. Under the inclusion model, students with special needs spend most or all of their time with non-disabled students. Inclusion rejects the use of special schools or classrooms to separate students with disabilities from students without disabilities. Implementation of these practices varies. Schools most frequently use the inclusion model for selected students with mild to moderate special needs. Fully inclusive schools, which are rare, do not separate "general education" and "special education" programs; instead, the school is restructured so that all students learn together. (Grenot-Scheyer et al., 1996, p.15).

Inclusive education is when all students, regardless of any challenges they may have, are placed in age-appropriate general education classes that are in their own neighborhood schools to receive high quality instruction, interventions, and supports that enable them to meet success in the core curriculum (Bui, Quirk, Almazan, \&Valenti, 2010; Alquraini\& Gut, 2012; Mittler, 2012, O’Connor, 2018, P 10).

Inclusive education differs from the "integration" or "mainstreaming" model of education, which tended to be concerned principally with disability and special educational needs, and learners changing or becoming ready for or deserving of accommodation by the mainstream. By contrast, inclusion is about the child's right to participate and the school's duty to accept the child. A premium is placed upon full participation by students with disabilities and upon respect for their social, civil, and educational rights. Feeling included is not limited to physical and cognitive disabilities, but also includes the full range of human diversity with respect to ability, language, culture, gender, age and of other forms of human differences. (Inclusive Design Research Centre, 2015, p.25).

Technology has always played an important role in teaching from time immemorial, but until recently, it has remained more on the periphery of education. Technology has been used mainly to support regular classroom teaching, or operated in the form of distance education, for a minority of students or in specialized departments (often in continuing education or extension). However, in the last ten to fifteen years, technology has been increasingly influencing the core teaching activities of even universities (Bates, 2015, p.37).

The accessibility of digital and online technologies for students with special educational needs may in part address some of the learning challenges experienced by them, their teachers and parents. Community based new technologies have been commonly suggested for all participants in the learning process. However, these technologies can also potentially grater for students with special educational needs (ZaraiiZavaraki and Toofaninejad 2011, Toofaninejad et al. 2017).

Various researchers have noted that despite the abundance of studies on the digital and online technologies, there are limited studies investigating learning through blended learning approach among students with special educational needs (Gerich and Fellinger 2012, Cuculick 2014, Gregor 2014, Hill 2015, Oyewumi et al. 2015, Kozuh et al. 2015, Saunders 2016, Toofaninejad et al. 2017). Hence, the systematic review undertaken in this paper aims to identify the studies that address the use of blended learning approach among students with special educational needs. The findings of the systematic review can provide insights into the challenges and opportunities encountered by educators, students and parents when using blended learning approach, and to better understand how the digital and online technologies can affect learning process of students with special educational needs. The study therefore addresses the following research questions:

1) How are blended learning approach used for students with special educational needs?

2) What are the major components of blended learning model for students with special educational needs?

3) What are the opportunities and challenges when implementing blended learning approach for students with special educational needs?

\section{Method}

\section{Search Strategy}


This systematic review was conducted using the Preferred Reporting Items for Systematic Reviews and Meta-Analyses (PRISMA) recommendation (Moher et al. 2009). To identify relevant studies, seven databases such as ERIC,Scopus, ProQuest, Web of Science,Wiley online library, Science Directand PsycINFO were searched. The search was conducted in June 2017 and further updated in November 2018.

The study was built using a combination of keywords in the domains of a) blended learning; b) special education; c) inclusive education. Keywords included "blended learning", "blended education", "hybrid education", "online learning", "e-learning", "digital learning", "technology-enhanced learning", and "computer supported learning". To locate all studies which related to special education, the keywords "special education", "students with disability", "exceptional childreen", and "exceptional education" were used. Finally, to address the educational aim of the study, keyword stems "inclusive education", and "inclusive school" were added.

\section{Study Selection Criteria}

The analysed dataset included studies that assessed the use of blended learning approach for students with special educational needs in inclusive education. Limitation was imposed on the date of publication and language of the studies. Studies were limited to years from 2008 to 2017 for a period of 10 years. Also, only studies published in English language were considered. Peer-reviewed published journal articles, conference proceedings, and doctoral dissertations were included, but not original research such as editorials, article book review and book chapters were excluded. The selection of the papers into the final dataset was limited to research conducted in blended learning approach for students with special educational needs. That is studies assessing the use of blended learning approach without a direct focus in or on special education were excluded.

\section{Results}

The selection process is outlined in Table 1. A total of 142 articles were identified using the noted search strategies. Having screened the titles and abstracts by the first author and his research assistants , 40 articles not focused on blended learning approach , 10 articles not focused on special education, 17 articles not original research such as editorials, article book review and book chapters, in 12 articles blended learning was used in education, but not in a special education setting, in 10 articles intervention was described as blended learning or an appropriate synonym, but was not a true blend, in 4 articles study discussed or mentioned blended learning but was evaluating something else . There for these articles excluded during the initial analysis.

Table 1. Reasons for excluding studies during the initial analysis $(\mathbf{n}=93)$.

\begin{tabular}{|c|c|c|}
\hline Row & Reason for exclusion & No. \\
\hline 1 & Not focused on blended learning approach & 40 \\
\hline 2 & Not focused on special education & 10 \\
\hline 3 & Not original research such as editorials, article book review and book chapters & 17 \\
\hline 4 & Blended learning was used in education, but not in a special education setting & 12 \\
\hline 5 & $\begin{array}{c}\text { Intervention was described as blended learning or an appropriate synonym, but was } \\
\text { not a true blend, i.e. the intervention was not integrated with online activities }\end{array}$ & 10 \\
\hline 6 & Study discussed or mentioned blended learning but was evaluating something else & 4 \\
\hline & & Total=93 \\
\hline
\end{tabular}

Although 49 articles were selected for full-text review, 27 articles were excluded by the first author and his research assistants due to the final application of the exclusion criteria such as: theoretical background and rationale of the study, research design, research sample, inclusion and exclusion criteria, data collection methods, reliability and validity of measures, data analysis strategy, ethical procedures and research outcomes. Finally, 22 eligible articles were selected for synthesis. Table 2 presents the final 22 studies that were selected for the review, following the critical appraisal.

\section{Data Extraction}

Table 2 presents the data of final 22 studies that were selected for the review. Information from the included articles in the systematic analysis was extracted using standardized forms and entered into Microsoft Excel. The following information was included in the Table 2: author and year of publication, title and country, sample and duration, type of special educational needs students (SEN), type of technology used, and results. 
Table 2. Type of research, educational goals and outcomes of included articles

\begin{tabular}{|c|c|c|c|c|c|c|c|}
\hline $\begin{array}{l}\text { Author and } \\
\text { year of } \\
\text { publication }\end{array}$ & Country & $\begin{array}{l}\text { Study } \\
\text { Design }\end{array}$ & $\begin{array}{c}\text { Target } \\
\text { population } \\
\text { and Sample }\end{array}$ & $\begin{array}{l}\text { Type of special } \\
\text { educational } \\
\text { needs students } \\
\text { (SEN) }\end{array}$ & $\begin{array}{l}\text { Type of } \\
\text { technology } \\
\text { used }\end{array}$ & Results & $\begin{array}{c}\text { Quality } \\
\text { assessme } \\
\text { nt }\end{array}$ \\
\hline $\begin{array}{l}\text { Nepo } \\
(2017)\end{array}$ & USA & $\mathrm{QL}$ & $\begin{array}{l}\text { students with } \\
\text { special needs }\end{array}$ & NA & $\begin{array}{l}\text { Integrated } \\
\text { technology }\end{array}$ & $\begin{array}{l}\text { Technology should be } \\
\text { incorporated throughout } \\
\text { the classroom } \\
\text { regardless of pre- } \\
\text { existing assumption of } \\
\text { educational services, } \\
\text { thereby assuring that all } \\
\text { students can be } \\
\text { instructed } \\
\text { necessary with } \\
\text { accommodations. }\end{array}$ & $46.3 \%$ \\
\hline $\begin{array}{l}\text { Zapf et al. } \\
\text { (2016) }\end{array}$ & USA & QNT & $\begin{array}{c}\text { elementary } \\
\text { and secondary } \\
\text { schools }\end{array}$ & $\begin{array}{l}\text { students with } \\
\text { hearing } \\
\text { impairment }\end{array}$ & $\begin{array}{l}\text { assistive } \\
\text { technology }\end{array}$ & $\begin{array}{l}\text { Characteristics of } \\
\text { student and teacher } \\
\text { combined can influence } \\
\text { the level of assistive } \\
\text { technology use. }\end{array}$ & $74.1 \%$ \\
\hline $\begin{array}{l}\text { Lersilp et al. } \\
\text { (2016) }\end{array}$ & Thailand & Mixed & $\begin{array}{l}\text { students with } \\
\text { disabilities }\end{array}$ & $\begin{array}{l}\text { students each } \\
\text { with visual, } \\
\text { hearing, } \\
\text { physical and } \\
\text { intellectual } \\
\text { disabilities }\end{array}$ & $\begin{array}{l}\text { assistive } \\
\text { technology }\end{array}$ & $\begin{array}{l}\text { Students with visual } \\
\text { disabilities needed } \\
\text { assistive technology the } \\
\text { most, but those with } \\
\text { hearing and physical } \\
\text { disabilities needed it the } \\
\text { least. }\end{array}$ & $74.4 \%$ \\
\hline $\begin{array}{l}\text { Majinge et al. } \\
\text { (2014) }\end{array}$ & Tanzania & Mixed & $\begin{array}{l}\text { professional } \\
\text { library, } \\
\text { disability unit } \\
\text { staff, people } \\
\text { with visual } \\
\text { impairment } \\
\text { from } \\
\text { the Ministry } \\
\text { of } \\
\text { Education's } \\
\text { Special Needs } \\
\text { Unit }\end{array}$ & $\begin{array}{c}\text { visual } \\
\text { impairment }\end{array}$ & $\begin{array}{c}\text { tape } \\
\text { recorder, } \\
\text { Braille } \\
\text { printer, } \\
\text { said a } \\
\text { scanner/rea } \\
\text { der, screen } \\
\text { enlargemen } \\
\text { t, } \\
\text { CCTV }\end{array}$ & $\begin{array}{l}\text { ICTs facilitate } \\
\text { information delivery to } \\
\text { people with visual } \\
\text { impairment and on } \\
\text { wheelchairs easily, } \\
\text { independently, remotely } \\
\text { using sources. In } \\
\text { addition ICTs are an } \\
\text { enabler of access by } \\
\text { students to learning } \\
\text { which increases } \\
\text { motivation, confidence, } \\
\text { their self-esteem and } \\
\text { enhances their } \\
\text { independence. }\end{array}$ & $65.6 \%$ \\
\hline $\begin{array}{l}\text { Mateu et al. } \\
\text { (2014) }\end{array}$ & Spanish & QNT & $\begin{array}{l}\text { students with } \\
\text { special needs }\end{array}$ & NA & $\begin{array}{l}\text { Virtual } \\
\text { Touch }\end{array}$ & $\begin{array}{l}\text { The results of this } \\
\text { experience } \\
\text { encouraging, showing } \\
\text { that mixed reality } \\
\text { applications have a high } \\
\text { potential as a means to } \\
\text { create educational } \\
\text { activities for use in } \\
\text { special education. }\end{array}$ & $50.0 \%$ \\
\hline $\begin{array}{c}\text { Sibon- } \\
\text { Macarro et al. } \\
(2014)\end{array}$ & USA & QNT & $\begin{array}{l}\text { students with } \\
\text { hearing } \\
\text { impairments }\end{array}$ & $\begin{array}{c}\text { hearing } \\
\text { impairments }\end{array}$ & $\begin{array}{l}\text { assistive } \\
\text { technology }\end{array}$ & $\begin{array}{l}\text { Classroom teachers and } \\
\text { service providers in all } \\
\text { areas need more } \\
\text { professional } \\
\text { development relevant } \\
\text { to working with } \\
\text { children with hearing } \\
\text { impairment and should } \\
\text { collaborate more with } \\
\text { special educators. }\end{array}$ & $70.7 \%$ \\
\hline
\end{tabular}




\begin{tabular}{|c|c|c|c|c|c|c|c|}
\hline $\begin{array}{l}\text { Staples et al. } \\
(2014)\end{array}$ & USA & QNT & $\begin{array}{l}\text { teachers of } \\
\text { severe } \\
\text { disabilities }\end{array}$ & $\begin{array}{c}\text { severe } \\
\text { disabilities }\end{array}$ & $\begin{array}{l}\text { software, } \\
\text { and } \\
\text { peripherals, } \\
\text { light/no } \\
\text { tech items, } \\
\text { mid- and } \\
\text { high-tech } \\
\text { items }\end{array}$ & $\begin{array}{l}\text { Two factors that } \\
\text { affected technology } \\
\text { integration in the } \\
\text { context of curriculum } \\
\text { reform: (a) the evolving } \\
\text { nature of curriculum } \\
\text { reform and (b) ongoing } \\
\text { interdisciplinary } \\
\text { collaboration. }\end{array}$ & $63.8 \%$ \\
\hline $\begin{array}{l}\text { Mullick } \\
\text { (2013) }\end{array}$ & USA & QL & $\begin{array}{l}\text { children with } \\
\text { and without } \\
\text { disabilities, } \\
\text { parents, } \\
\text { teachers, } \\
\text { therapists, } \\
\text { daycare } \\
\text { owners and } \\
\text { designers }\end{array}$ & $\begin{array}{l}\text { children with } \\
\text { disabilities }\end{array}$ & $\begin{array}{l}\text { Print based } \\
\text { technology } \\
\text { and } \\
\text { computer } \\
\text { based } \\
\text { technology }\end{array}$ & $\begin{array}{l}\text { Children's drawings, } \\
\text { and play simulation can } \\
\text { promoting social } \\
\text { inclusion and they met } \\
\text { the criteria of the } \\
\text { Inclusive Indoor Play } \\
\text { project. Play concept } \\
\text { must be employed to } \\
\text { design playthings for } \\
\text { children with } \\
\text { disabilities. }\end{array}$ & $67.1 \%$ \\
\hline $\begin{array}{l}\text { Nam et al. } \\
\text { (2013) }\end{array}$ & USA & QNT & $\begin{array}{l}\text { schools for } \\
\text { the visually } \\
\text { and/or } \\
\text { auditory } \\
\text { impaired }\end{array}$ & $\begin{array}{l}\text { blind and/or } \\
\text { the deaf }\end{array}$ & $\begin{array}{c}\text { assistive } \\
\text { technology }\end{array}$ & $\begin{array}{l}\text { The results of the } \\
\text { present study should } \\
\text { provide some insights } \\
\text { into the understanding } \\
\text { of AT acceptance and } \\
\text { the decisions of AT } \\
\text { utilization, as well as its } \\
\text { distribution } \\
\text { training. }\end{array}$ & $71.7 \%$ \\
\hline $\begin{array}{c}\text { Bouck et al. } \\
\text { (2012) }\end{array}$ & USA & QNT & $\begin{array}{l}\text { parent and } \\
\text { student's } \\
\text { school } \\
\text { program }\end{array}$ & $\begin{array}{l}\text { high-incidence } \\
\text { disabilities }\end{array}$ & $\begin{array}{c}\text { assistive } \\
\text { technology }\end{array}$ & $\begin{array}{l}\text { Little assistive } \\
\text { technology reported } \\
\text { being received at the } \\
\text { end of secondary } \\
\text { education by students } \\
\text { with high-incidence } \\
\text { disabilities. }\end{array}$ & $50.0 \%$ \\
\hline $\begin{array}{l}\text { Hanline et al. } \\
\quad(2012)\end{array}$ & USA & Mixed & $\begin{array}{l}\text { teachers of } \\
\text { learners } \\
\text { with severe } \\
\text { disabilities }\end{array}$ & $\begin{array}{c}\text { severe } \\
\text { disabilities }\end{array}$ & $\begin{array}{l}\text { Network } \\
\text { based } \\
\text { technology }\end{array}$ & $\begin{array}{l}\text { Results are discussed in } \\
\text { relation to providing } \\
\text { online personnel } \\
\text { development r for } \\
\text { teachers of learners } \\
\text { with severe disabilities. }\end{array}$ & $61.1 \%$ \\
\hline $\begin{array}{l}\text { Ratliffe et al. } \\
\text { (2012) }\end{array}$ & USA & $\mathrm{QL}$ & NA & disabilities & $\begin{array}{l}\text { computer } \\
\text { based } \\
\text { technology } \\
\text { and } \\
\text { Network } \\
\text { based } \\
\text { technology }\end{array}$ & $\begin{array}{l}\text { ICTs can be used to } \\
\text { empower individuals } \\
\text { with disabilities, create } \\
\text { conditions for self- } \\
\text { advocacy and inclusion, } \\
\text { and counter negative } \\
\text { perceptions } \\
\text { disability. } \\
\text { Access to technology is } \\
\text { becoming increasingly } \\
\text { important for all People } \\
\text { with disabilities. }\end{array}$ & $59.8 \%$ \\
\hline $\begin{array}{l}\text { Kincaid } \\
\text { (2012) }\end{array}$ & Canada & $\mathrm{QL}$ & $\begin{array}{c}\text { teachers } \\
\text { supporting } \\
\text { students who } \\
\text { are deaf and } \\
\text { hard-of- } \\
\text { hearing }\end{array}$ & $\begin{array}{l}\text { deaf and hard- } \\
\text { of-hearing }\end{array}$ & $\begin{array}{c}\text { Audio } \\
\text { based } \\
\text { technology }\end{array}$ & $\begin{array}{l}\text { Data revealed the } \\
\text { participants used an } \\
\text { auditory and verbal } \\
\text { approach to teaching } \\
\text { literacy to Deaf and } \\
\text { Hard-of-Hearing } \\
\text { students. This aligned } \\
\text { with their school } \\
\text { boards' educational } \\
\text { model and instructional }\end{array}$ & $80.5 \%$ \\
\hline
\end{tabular}




\begin{tabular}{|c|c|c|c|c|c|c|c|}
\hline & & & & & & approach. & \\
\hline $\begin{array}{c}\text { Trepagnier et } \\
\text { al. } \\
(2011)\end{array}$ & USA & QNT & $\begin{array}{l}\text { adolescents } \\
\text { and adults } \\
\text { with autism }\end{array}$ & autism & $\begin{array}{l}\text { computer } \\
\text { based } \\
\text { technology }\end{array}$ & $\begin{array}{l}\text { If simulated } \\
\text { conversational } \\
\text { experience can be } \\
\text { shown to bring about } \\
\text { improvement in } \\
\text { interactive language } \\
\text { pragmatics, it will be } \\
\text { possible to provide } \\
\text { an inexpensive, } \\
\text { accessible, and, if } \\
\text { desired, private addition } \\
\text { to the social skills } \\
\text { supports greatly needed } \\
\text { by many adults with } \\
\text { ASD. }\end{array}$ & $55.0 \%$ \\
\hline $\begin{array}{c}\text { Van } \\
\text { Laarhoven et } \\
\text { al. } \\
(2011)\end{array}$ & USA & QNT & $\begin{array}{l}\text { special } \\
\text { education } \\
\text { teacher }\end{array}$ & $\begin{array}{c}\text { mild, } \\
\text { moderate, } \\
\text { and severe } \\
\text { disabilities }\end{array}$ & $\begin{array}{c}\text { assistive } \\
\text { technology }\end{array}$ & $\begin{array}{l}\text { Even the Introduction to } \\
\text { Special Education } \\
\text { course and the } \\
\text { Collaboration course } \\
\text { emphasize the } \\
\text { importance of using } \\
\text { ATs to support students } \\
\text { with accessing the } \\
\text { general education } \\
\text { curriculum. }\end{array}$ & $60.0 \%$ \\
\hline $\begin{array}{l}\text { Gronseth } \\
\text { (2011) }\end{array}$ & USA & Mixed & students & $\begin{array}{c}\text { mild } \\
\text { disabilities \& } \\
\text { students with } \\
\text { specific } \\
\text { learning } \\
\text { disabilities \& } \\
\text { students with } \\
\text { emotional and } \\
\text { behavioral } \\
\text { disorders }\end{array}$ & $\begin{array}{c}\text { assistive } \\
\text { technology }\end{array}$ & $\begin{array}{l}\text { It was found that about } \\
\text { a quarter of the students } \\
\text { in the analytic sample } \\
\text { used AT. Students in } \\
\text { mathematics classes } \\
\text { were almost four times } \\
\text { more likely to use AT } \\
\text { than students in other } \\
\text { subject area classes. } \\
\text { Students in classes that } \\
\text { incorporated whole } \\
\text { class computer- based } \\
\text { activities were more } \\
\text { than twice as likely to } \\
\text { use AT as students in } \\
\text { classes that rarely } \\
\text { incorporated } \\
\text { activities. such }\end{array}$ & $84.4 \%$ \\
\hline $\begin{array}{l}\text { Urdang } \\
\text { (2011) }\end{array}$ & USA & Mixed & $\begin{array}{l}\text { directors of } \\
\text { special } \\
\text { services in } \\
\text { schools }\end{array}$ & $\begin{array}{c}\text { special } \\
\text { education } \\
\text { students }\end{array}$ & $\begin{array}{l}\text { assistive } \\
\text { technology }\end{array}$ & $\begin{array}{l}\text { Surveys and interviews } \\
\text { indicated that AT } \\
\text { decisions are typically } \\
\text { made before and } \\
\text { during placement } \\
\text { decisions. AT is } \\
\text { considered during the } \\
\text { IEP process and the IEP } \\
\text { team acts as the } \\
\text { decision-maker } \\
\text { regarding AT. Directors } \\
\text { reported that AT is } \\
\text { often considered among } \\
\text { a student's needs. }\end{array}$ & $83.0 \%$ \\
\hline $\begin{array}{c}\text { Bonnah et al. } \\
\quad(2010)\end{array}$ & Ghana & Mixed & $\begin{array}{l}\text { people with } \\
\text { disabilities \& } \\
\text { teacher }\end{array}$ & deaf \& blind & $\begin{array}{l}\text { computer } \\
\text { based } \\
\text { technology } \\
\text { and } \\
\text { Network } \\
\text { based } \\
\text { technology }\end{array}$ & $\begin{array}{lr}\text { ICT scan indeed } \\
\text { contribute significantly } \\
\text { to the learning } \\
\text { processes of people } \\
\text { with disabilities. } \\
\text { Governments across } \\
\text { Africa must } & \text { take }\end{array}$ & $65.6 \%$ \\
\hline
\end{tabular}




\begin{tabular}{|c|c|c|c|c|c|c|c|}
\hline & & & & & & $\begin{array}{l}\text { positive action to ensure } \\
\text { that such experience } \\
\text { with ICTs can be used } \\
\text { to enable those with } \\
\text { SEN to achieve their } \\
\text { full potential, whether } \\
\text { in schools or } \\
\text { special within } \\
\text { included mainstream education. } \\
\text { main }\end{array}$ & \\
\hline $\begin{array}{l}\text { Chiang \& } \\
\text { Jacobs } \\
(2010)\end{array}$ & NA & QL & $\begin{array}{c}\text { students with } \\
\text { special needs } \\
\& \text { teachers }\end{array}$ & NA & $\begin{array}{l}\text { computer } \\
\text { based } \\
\text { technology }\end{array}$ & $\begin{array}{l}\text { Student participants } \\
\text { noted that CBI was } \\
\text { helpful when they were } \\
\text { engaged in functional } \\
\text { activities related to } \\
\text { reading and writing. }\end{array}$ & $67.1 \%$ \\
\hline $\begin{array}{c}\text { McPherson \& } \\
\text { King } \\
(2010)\end{array}$ & USA & Mixed & students & $\begin{array}{l}\text { special } \\
\text { education } \\
\text { students }\end{array}$ & $\begin{array}{l}\text { Network } \\
\text { based } \\
\text { technology }\end{array}$ & $\begin{array}{l}\text { Before embarking on an } \\
\text { international special } \\
\text { education distance } \\
\text { learning } \\
\text { program, institutions } \\
\text { would be wise to } \\
\text { consider what resources } \\
\text { are available in the } \\
\text { language, } \\
\text { what type of student } \\
\text { support system to put in } \\
\text { place, how to enhance } \\
\text { intercultural dialogue, } \\
\text { and hy to translate the } \\
\text { how to } \\
\text { courses to reflect the } \\
\text { international students' } \\
\text { language and culture. }\end{array}$ & $87.8 \%$ \\
\hline $\begin{array}{c}\text { Huang et al. } \\
\text { (2009) }\end{array}$ & Taiwan & $\mathrm{QL}$ & $\begin{array}{l}\text { children \& } \\
\text { mothers and } \\
\text { teacher }\end{array}$ & cerebral palsy & NA & $\begin{array}{l}\text { The findings not only } \\
\text { demonstrate the } \\
\text { significance of child- } \\
\text { environment interaction } \\
\text { but also provide } \\
\text { evidence that children's } \\
\text { views may be different } \\
\text { from those of adults } \\
\text { because they are at a } \\
\text { different developmental } \\
\text { stage and act out } \\
\text { different roles in their } \\
\text { environment. }\end{array}$ & $73.2 \%$ \\
\hline $\begin{array}{c}\text { Lee \& } \\
\text { Templeton } \\
(2008)\end{array}$ & NA & QL & $\begin{array}{l}\text { students with } \\
\text { special needs }\end{array}$ & $\begin{array}{c}\text { Mild } \\
\text { disabilities, } \\
\text { sensory } \\
\text { impairments, } \\
\text { ever and/or } \\
\text { multiple } \\
\text { disabilities }\end{array}$ & $\begin{array}{l}\text { assistive } \\
\text { technology }\end{array}$ & $\begin{array}{l}\text { Empirical studies } \\
\text { consistently show that } \\
\text { the use of AT promotes } \\
\text { self-confidence, } \\
\text { freedom, independence, } \\
\text { and meaningful } \\
\text { participation in } \\
\text { home, school, and } \\
\text { community. }\end{array}$ & $47.6 \%$ \\
\hline
\end{tabular}

$\mathrm{NA}=$ Not mentioned, $\mathrm{QL}=$ Qualitative research design, $\mathrm{QNT}=$ Quantitative research design, CCTV $=$ Closed-Circuit Television, ICT = Information and Communications Technology, AT= Assistive Technology, ASD= Autism spectrum Disorder, $\mathrm{CBI}=$ Computer Based Instruction, IEP= Individualized Education Program

\section{Quality Assessment of Studies}

The included studies were also evaluated in regard to their quality. The checklist developed by Batten and colleagues (2014) was used for undertaking a quality assessment. 
Studies listed in Table 2 fell within the quality range from 46.3\% (Nepo, 2017) to 87.8\% (McPherson and King 2010). The average quality of all the included studies was $66.3 \%$. The percentage of all included articles mentioned in Table 2 .

\section{Sample}

The samples consisted of students with special needs, students with disabilities, elementary and secondary schools, professional library, disability unit staff, people with visual impairment, students with hearing impairments, teachers of learners with severe disabilities, children with and without disabilities, parents, teachers, therapists, daycare owners and designers, schools for the visually and/or auditory impaired, parent and student's school program, teachers supporting students who are deaf and hard-of-hearing, adolescents and adults with autism, special education teacher and directors of special services in schools.

According to Table 2, following types of special educational needs students (SEN) included in the selected studies: students with visual, hearing, physical and intellectual disabilities, visual impairments, hearing impairments, blind and/or the deaf, high-incidence disabilities, deaf and hard-of-hearing, autism, mild, moderate, and severe disabilities, mild disabilities \& students with specific learning disabilities \& students with emotional and behavioral disorders, cerebral palsy and mild disabilities, sensory impairments, ever and/or multiple disabilities.

Thus, the sample of these studies indicate that blended learning approach has been implemented for many types of special educational needs students (SEN), although it is not all of them.

\section{Location}

The studies were conducted in the USA (14), Canada (1), Spanish (1), Taiwan (1), Tanzania (1), Thailand (1), and Ghana (1), not mentioned name of country (2). We found that the most of studies were conducted in developed countries. Students in these developed nations could generally be expected to have access to the new technologies such as computer and network based technologies and integrated technologies in their schools, universities, homes and society that makes blended learning a feasible option. However, blended learning is highly context dependent (Nepo, 2017), making it difficult to generalise results between populations and geographical location.

The poor of evidence of a blended learning approach to special education in developing countries may be an indicator of some of the challenges associated with technological innovation in areas with poor infrastructure. Indeed, epistemological and physical access to technology has been highlighted as a major challenge in the implementation of technology-enhanced teaching and learning practice in developing countries (Huang et al., 2009).

\section{Study Design}

A range of study designs were used, with and without control groups, indicating a variety of methods to determine the efficacy of the blended learning approach in special education. These included quantitative, qualitative and mixed research methods. As shown in Table 2, 8 studies used quantitative methods, 7 were a qualitative study and 7 employed mixed methods.

\section{Discussion}

This systematic review aimed to investigate how blended learning approach used for students with special educational needs, exploring of the major components of blended learning model and identify the opportunities and challenges of blended learning approach when implementing for students with special educational needs. Table 2 provides an overview of the reviewed studies aims and reported outcomes. The analyses demonstrate that the most of studies concluded that the use of blended learning approach had an overall positive effect on various aspects of students with special educational needs, although in developing countries may be have some of the challenges.

This section discusses the findings of these studies by addressing three following main questions.

\section{How are blended learning approach used for students with special educational needs?}

The systematic review of the literature demonstrates that computer and network based technology can improve students with special educational needs performance when used in blended learning environments (Nepo2017, Ratliffe et al. 2012, Chiang \& Jacobs 2010, and McPherson\& King2010). People with disabilities require access to ICT tosupport, maintain and extend their capabilities to participate alongside their peers (Ratliffe et al. 2012). ICTs can be used to enable those with SEN to achieve their full potential, whether in special schools or included within mainstream education (Bonnah et al.2010). 
The types of technologies that used in blended learning approach for students with special educational needs are: assistive technology, tape recorder, Braille printer, screen enlargement, CCTV, Virtual Touch, Software and peripherals, light/no tech items, mid- and high-tech items, print based technology, audio based technology, computer based technology, network based technology, and integrated technology. The authors fond that assistive technology, computer based technology and network based technology are most popular technologies that used in blended learning approach for students with special educational needs such as : students with hearing impairment, students with visual impairment, students with visual, hearing, physical and intellectual disabilities, students with specific learning disabilities, students with emotional and behavioral disorders, , students with physical -motor disorders, and students with multiple disabilities.

\section{What are the major components of blended learning model for students with special educational needs?}

The authors of the article, with the help of their research assistants, made extensive efforts to find the main components of the blended learning approach to special education based on the 22 selected studies. Based on the 22 selected studies, the components of the blended learning approach for students with special educational needs are:

Goal, learner, teacher, the content, media, message, learning environment, learning space, educational resources and learning resources, technology, learning theories, purpose, methods, strategies, learning activities, measurement techniques, educational services, resources, material, enrichment, interaction , participation , engagement, facilitate, coordination, collaboration, learner support, teacher support ,course support, simulation, augmentative and alternative communication, online learning, diverse classrooms, hardware adaptations, specialized software, communication aids , assessment and evaluation.

What are the opportunities and challenges when implementing blended learning approach for students with special educational needs?

According to Table 2, blended learning approach for students with special educational needs have some opportunities and challenges. Based on the 22 selected studies, the opportunities and challenges of the blended learning approach for students with special educational needs are following:

The opportunities are: 1) Facilitate information delivery (Majinge et al. 2014, Trepagnier et al. 2011), 2) Using sources (Majinge et al. 2014, Trepagnier et al. 2011),3)Increases motivation, confidence, self -esteem and enhances their independences (Majinge et al. 2014, Lee \& Templeton 2008),

4)Create educational activities for use of special education(Mateu et al. 2014),5) Collaboration between classroom teachers and service providers and special educators(Sibon-Macarroet al. 2014), 6)Promoting social inclusion(Mullick 2013), 7)Providing online personnel development for teachers of learners with severe disabilities(Hanline et al. 2012),8)Empower individuals with disabilities, create conditions for self-advocacy and inclusion, and counter negative perceptions of disability(Ratliffe et al. 2012), 9)Supporting students with accessing the general education curriculum (Van Laarhoven et al. 2011,Gronseth 2011), 10)Enable those with SEN to achieve their full potential, whether in special schools or included within mainstream education(Bonnah et al. 2010), 11)Environment interaction(Huang et al. 2009).

The challenges are: 1)Accessibility to technology particularly in developing countries(Nepo 2017, Lersilp et al. 2016, Bouck et al. 2012, Ratliffe et al. 2012), 2) Backgrounds of student and teachers(Zapf et al. 2016, Van Laarhoven et al. 2011, McPherson \& King 2010), 3) Interdisciplinary collaborations(Staples et al. 2014).

\section{Limitation}

While every attempt was made to incorporate as much of the current evidence as was available, only a limited number of articles could be found for this review. The lack of studies with experimental designs, random assignment, and controls for the influence of extraneous variables appears to be a challenge and questions the quality of the current findings. None of the studies used experimental methods with a designated control group. However, owing to the rapidly developing field of technology and the emergence of blended learning as a flexible approach in special education, it is likely that publications already exist that would enhance or challenge the results of this review.

\section{Conclusion}

There is limited research available on the appropriate use of online learning environments as part of a blended learning approach to the all groups of students with special educational needs. However, in the small number of studies that implemented a blended learning approach for SEN, there was some evidence of opportunities. The study helped understand how blended learning approach used for SEN, the major components of blended learning model for students with SEN and the opportunities and challenges when implementing blended learning approach for students with SEN. A systematic search revealed a total of 142 studies. 
From the sample, 22articles met the eligible criteria. The systematic review of the literature demonstrates that computer and network based technology can improve performance of students with special educational needs when used in blended learning environments. In addition, assistive technology, computer based technology and network based technology are most popular technologies that used in blended learning approach for students with SEN.The findings also suggest that approach, environment, learner, tools, support, assessment and evaluation are the major components of the blended learning model for students with SEN.

The results also support the view that the blended learning approach has much potential to aid students with SEN. Based on the 22 selected studies, some of these opportunities for the blended learning approach for students with special educational needs are: facilitate information delivery, using sources, increases motivation, confidence, self esteem and enhances their independences, create educational activities for use in special education, collaboration between classroom teachers and service providers and special educators, promoting social inclusion, providing online personnel development for teachers of learners with severe disabilities, empower individuals with disabilities, create conditions for self-advocacy and inclusion, and counter negative perceptions of disability, supporting students with accessing the general education curriculum, enable those with SEN to achieve their full potential, whether in special schools or included within mainstream education and environment interaction. However, some challenges such as: accessibility to technology particularly in developing countries, backgrounds of student and teachers and interdisciplinary collaborations found that very important in this area.

According to the main components of the blended learning approach to special education, the authors proposed conceptual model that could be used as a guideline for further related research studies. The results of this review indicate that further research in this area is necessary.

\section{Statements on open data, ethics and conflicts of interest}

The article is the authors' original work and does not contain any libelous or unlawful statements or infringe on the rights or privacy of others or contain material or instructions that might cause harm or injury. The article has not been previously published, is not pending review elsewhere, and will not be submitted for review elsewhere pending the completion of the editorial decision process at the journal. Any part of the data on which the article depends has not been published elsewhere and it is not part of another manuscript submitted for publication. The data for my study is not part of a larger data set.

\section{Acknowledgements}

We are thankful from the AllamehTabataba'i University and the University of Geneva, which provided us with the financial and material support, facilities and resources necessary for this important scientific work.

\section{References}

Abbott, S., Guisbond, L., Levy, J., \& Sommerfeld, M. (2014). The glossary of education reform. Retrieved from. http://edglossary.org/learning-environment/ (25/11/2018)

Alquraini, T., \& Gut, D. (2012). Critical components of successful inclusion of students with severe disabilities: Literature review. International Journal of Special Education, 27(1), 42-59.

Bates, T. (2015). Teaching in a Digital Age (Doctoral dissertation, University of British Columbia).

Bonnah Nkansah, Godfred \& Unwin, Tim. (2010). The contribution of ICTs to the delivery of special educational needs in Ghana: practices and potential. Information Technology for Development , 16 (3) 191-211: Special Issue: ICT Education in Development.

Bouck, Emily C.; Maeda, Yukiko \& Flanagan, Sara M. .(2012). Assistive Technology and Students With Highincidence Disabilities Understanding the Relationship Through the NLTS2. Remedial and Special Education. 33 (5), 298-308.

Bui, X., Quirk, C., Almazan, S., \&Valenti, M. (2010). Inclusive education research and practice. Maryland Coalition for Inclusive Education, 1-14.

Chiang, HY, \& Jacobs, Karen. (2010). Perceptions of a computer-based instruction system in special education: high school teachers and students views. Work. 2010; 37(4):349-59. doi: 10.3233/WOR-2010-1089.

Christensen, C. M., Horn, M. B., \&Staker, H. (2013). Is K-12 Blended Learning Disruptive? An Introduction to the Theory of Hybrids. Clayton Christensen Institute for Disruptive Innovation.

Cuculick, J. A., (2014). Facebooking among deaf college students: Deaf-gain and Funds of Knowledge. Thesis (PhD). 
University of Rochester. Retrieved from http://hdl.handle.net/1802/28353

Garrison, D. R. (2016). E-learning in the 21st Century: A Community of Inquiry Framework for Research and Practice. Routledge.

Garrison, D. R., \&Kanuka, H. (2004). Blended learning: Uncovering its transformative potential in higher education. The internet and higher education, 7(2), 95-105.

Gerich, J., and Fellinger, J., (2012). Effects of social networks on the quality of life in an elder and middle-aged deaf community sample. Journal of Deaf Studies and Deaf Education, 17(1), 102-115. doi:10.1093/deafed/enr022

Gregor, S. E., (2014). Social Networking: Closing the Achievement Gap Between Regular and Special Education Students. Thesis (PhD). Nova Southeastern University. Retrieved from http://nsuworks.nova.edu/fse_etd/7/

Grenot- Scheyer, M. et al. (1996). The inclusive classroom teacher created materials. Inc. The inclusive classroom, USA.

Gronseth, S.L. (2011). Factors that impact the use of assistive technologies to support secondary students with mild disabilities. Ph.D. thesis, Indiana University. Retrieved November 21, 2018 from

https://www.learntechlib.org/p/120024/.

Hanline, Mary Frances; Hatoum, Rima J. \& Riggie, Jennifer.(2012). Impact of Online Coursework for Teachers of Students with Severe Disabilities: Utilization of Knowledge and its Relationship to Teacher Perception of Competence. Research and Practice for Persons with Severe Disabilities, 37 ( 4), 247-262.

Hill, C. L., (2015). An investigation of the connections between use of facebook and the self-esteem/well-being of students with disabilities in the university of iowa reach program. Thesis $(\mathrm{PhD})$. University of Iowa. Retrieved from http://ir.uiowa.edu/etd/1335/

Horn, M. B., \&Staker, H. (2014). Blended: Using disruptive innovation to improve schools. John Wiley \& Sons.

Huang, I.-C., Sugden, D., \& Beveridge, S. (2009). Assistive devices and cerebral palsy: The use of assistive devices at school by children with cerebral palsy. Child: Care, Health and Development, 35(5), 698-708. http://dx.doi.org/10.1111/j.1365-2214.2009.00968.x.

Inclusive Design Research Centre. (2015). What is inclusive design. OCAD University. Retrieved 13 November 2015.

Kincaid, Patricia Mable Teresa.(2012). Exploring the use of auditory and verbal strategies and specific visual teaching systems of itinerant teachers of students who are deaf and hard-of-hearing. M.A thesis, the Department of Education, Queen's University Kingston, Ontario, Canada.

Kozuh, I., et al.,(2015). Enhancing universal access: deaf and hard of hearing people on social networking sites. Universal Access in the Information Society, 14(4), 537-545. doi:10.1007/s10209-014-0354-3

Lee, Hwa. \& Templeton, Rosalyn. (2008). Ensuring Equal Access to Technology: Providing Assistive Technology for Students with Disabilities. Theory into Practice, 47 (3), 212-219.

Lersilp, S., Putthinoi, S., \& Chakpitak, N. (2016). Model of Providing Assistive Technologies in Special Education Schools. Global journal of health science, 8(1), 36.

Majinge, R. M., \& Stilwell, C. (2014). ICT Use in Information Delivery to People with Visual Impairment and on Wheelchairs in Tanzanian Academic Libraries. African Journal of Library, Archives \& Information Science, 24(2).

Mateu, J., Lasala, M. J., \& Alamán, X. (2014). VirtualTouch: a tool for developing mixed reality educational applications and an example of use for inclusive education. International Journal of Human-Computer Interaction, 30(10), 815-828.

McPherson, Rebekah \& King, Kelley M. (2010). International distance learning in special education: A program evaluation of a US-Ecuador collaboration. Ph.D. thesis, University of North Texas Retrieved November 21, 2018 from https://digital.library.unt.edu/ark:/67531/metadc30493/.

Mittler, P. (2012). Working towards inclusive education: Social contexts. David Fulton Publishers.

Moher, D., et al., 2009. Preferred Reporting Items for Systematic Reviews and Meta-Analyses: The PRISMA Statement (Reprinted from Annals of Internal Medicine). Physical Therapy, 89(9), 873-880. doi:10.1371/journal.pmed.1000097.

Mullick, Abir. (2013). Inclusive indoor play: An approach to developing inclusive design guidelines, Technology and Disability, 44(1), 5-17.

Nam, Chang S., Bahn, Sangwoo \& Lee, Raney.(2013). Acceptance of Assistive Technology by Special Education Teachers: A Structural Equation Model Approach. International Journal of Human-Computer Interaction. DOI:10.1080/10447318.2012.711990.

Nepo, K. (2017, April). The use of technology to improve education. In Child \& Youth Care Forum (Vol. 46, No. 2, pp. 207-221). Springer US.

O’Connor, J., Gleason, C. M., \& Santi, K. L. (2018). Setting a Framework of Inclusive Support for Students with Disabilities. Cultivating Inclusive Practices in Contemporary K-12 Education, 1. 
Oyewumi, A., Isaiah, O., and Adigun, O., 2015. Influence of social networking on the psychological adjustment of adolescents with hearing impairment in Ibadan , Oyo State , Nigeria. Net Journal of Social Sciences, 3(1), 1724. Retrieved from http://www.netjournals.org/z_NJSS_15_015.html

Powell, A., Roberts, V., \& Patrick, S. (2015). Using Online Learning for Credit Recovery: Getting Back on Track to Graduation. Promising Practices in Blended and Online Learning Series. International Association for K-12 Online Learning.

Powell, A., Watson, J., Staley, P., Patrick, S., Horn, M., Fetzer, L. \&Verma, S. (2015). Blending Learning: The Evolution of Online and Face-to-Face Education from 2008-2015. Promising Practices in Blended and Online Learning Series. International association for K-12 online learning.

Ratliffe, Katherine T.; Rao, Kavita; Skouge, James R. \& Peter, Joakim.(2012). Navigating the currents of change: technology, inclusion, and access for people with disabilities in the Pacific. Information Technology for Development, 18 (3), 209-225.

Saunders, K. C., (2016). A Double-Edged Sword: Social Media as a Tool of Online Disinhibition Regarding American Sign Language and Deaf Cultural Experience Marginalization, and as a Tool of Cultural and Linguistic Exposure. Social Media + Society, 2(1), 205630511562452. doi:10.1177/2056305115624529

Sibon-Macarro, T., Abou-Rjaily, K., Stoddard, S., Sandigo, A., Peterson, P., \& Ross, V. (2014). Rural perspectives of models, services, and resources for students with hearing impairments. Rural Special Education Quarterly, 33(4), 24-32.

Staker, H., \& Horn, M. B. (2014). Blended learning in the K-12 education sector. Blended learning research perspectives, 2, 287-303.

Staples, A., \& Edmister, E. (2014). The reintegration of technology as a function of curriculum reform: Cases of two teachers. Research and Practice for Persons with Severe Disabilities, 39(2), 136-153.

Toofaninejad, E., Zaraii Zavaraki, E., Dawson, S., Poquet, O., \& Sharifi Daramadi, P. (2017). Social media use for deaf and hard of hearing students in educational settings: a systematic review of literature. Deafness \& Education International, 19(3-4), 144-161.

Trepagnier, Cheryl Y.; Olsen, Dale E.; Boteler, Laura \& Bell, Corinne A. .(2011). CYBERPSYCHOLOGY, BEHAVIOR, AND SOCIAL NETWORKING. 14(1-2): 21-27.

Urdang, A.H. (2011). Assistive Technology and Inclusive Education: Investigating Decision-Making and Implementation in New Jersey Schools through Surveys and Interviews with District Directors of Special Services. Ph.D. thesis, The State University of New Jersey. Retrieved November 21, 2018 from https://rucore.libraries.rutgers.edu/rutgers-lib/33414/.

Van Laarhoven, T. \& Conderman, G. (2011). Integrating Assistive Technology into Special Education Teacher Preparation Programs. Journal of Technology and Teacher Education, 19(4), 473-497. Waynesville, NC USA: Society for Information Technology \& Teacher Education. Retrieved November 22, 2018 from https://www.learntechlib.org/primary/p/33299/.

Zapf, S. A., Scherer, M. J., Baxter, M. F., \& H. Rintala, D. (2016). Validating a measure to assess factors that affect assistive technology use by students with disabilities in elementary and secondary education. Disability and Rehabilitation: Assistive Technology, 11(1), 38-49.

Zaraii Zavaraki, E., and Toofaninejad, E., (2011). The effect of blended learning on student's achievement. In proceedings of global learn Asia Pacific 2011 (pp. 1913-1916). Retrieved from https://www.learntechlib.org/p/37422. 